\title{
Identification of Volatile and Semi-Volatile Compounds in Polymeric Coatings Used in Metal Cans by GC-MS and SPME
}

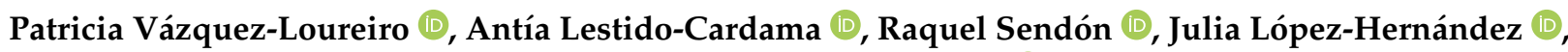 \\ Perfecto Paseiro-Losada and Ana Rodríguez-Bernaldo de Quirós * (i)
}

check for

updates

Citation: Vázquez-Loureiro, P.; Lestido-Cardama, A.; Sendón, R.;

López-Hernández, J.; Paseiro-Losada,

P.; Rodríguez-Bernaldo de Quirós, A.

Identification of Volatile and

Semi-Volatile Compounds in

Polymeric Coatings Used in Metal

Cans by GC-MS and SPME. Materials

2021, 14, 3704. https://doi.org/

$10.3390 /$ ma14133704

Academic Editor: Csaba Balázsi

Received: 2 June 2021

Accepted: 28 June 2021

Published: 2 July 2021

Publisher's Note: MDPI stays neutral with regard to jurisdictional claims in published maps and institutional affiliations.

Copyright: (c) 2021 by the authors. Licensee MDPI, Basel, Switzerland. This article is an open access article distributed under the terms and conditions of the Creative Commons Attribution (CC BY) license (https:// creativecommons.org/licenses/by/ $4.0 /)$.
Department of Analytical Chemistry, Nutrition and Food Science, Faculty of Pharmacy, University of Santiago de Compostela, 15782 Santiago de Compostela, Spain; patriciavazquez.loureiro@usc.es (P.V.-L.); antia.lestido@usc.es (A.L.-C.); raquel.sendon@usc.es (R.S.); julia.lopez.hernandez@usc.es (J.L.-H.); perfecto.paseiro@usc.es (P.P.-L.)

* Correspondence: ana.rodriguez.bernaldo@usc.es; Tel.: +34-88-181-4965

\begin{abstract}
Polymeric coatings are used as a protective layer to preserve food or beverage quality and protect it from corrosion and avoid a metallic taste. These types of materials can contain some chemicals that are susceptible to migrate to food and constitute a risk for consumers' health. This study is focused on the identification of volatile and semi-volatile low molecular weight compounds present in polymeric coatings used for metal food and beverage cans. A method based on solidliquid extraction followed by gas chromatography-mass spectrometry (GC-MS) was optimized for the semi-volatile compounds. Different solvents were tried with the aim of extracting compounds with different polarities. Furthermore, a method based on solid-phase microextraction (SPME) in headspace (HS) mode and gas chromatography coupled with mass spectrometry (HSSPME-GC-MS) was developed for the identification of potential volatile migrants in polymeric coatings. Some parameters such as extraction time, equilibrium temperature, or the type of fiber were optimized. Different compounds, including aldehydes such as octanal or nonanal, alcohols such as $\alpha$-terpineol or 2-butoxyethanol, ethers, alkenes, or phthalic compounds, among others, were identified and confirmed with analytical standards both via SPME analysis as well after solvent extraction.
\end{abstract}

Keywords: potential migrants; polymeric coatings; GC-MS; SPME

\section{Introduction}

Migration of components from food contact material to food is a matter of concern from the food safety point of view. Special attention has been paid to low molecular weight compounds and particularly to unknown compounds. Their identification is a current challenge in the food packaging field [1].

Different materials have traditionally been used in food packaging including glass, metals, paper, paperboards, and plastics. Marsh et al. [2] reported some advantages and disadvantages of these typical materials used in beverage packaging, such as the susceptibility to breakages or the heavy weight in the case of glass. Metal cans are widely used, and they have several advantages over other materials as they are able to tolerate high temperature and pressure conditions [3]. Polymeric coatings are used as functional barriers between food and metal cans. They preserve the quality of food in terms of flavor, odor, and color, as well as extend shelf-life and help the metal can in protecting food from external agents such as light, oxygen, and microorganisms, and facilitate transport and storage of the canned food.

Beverage packaging often combines several materials to exploit these properties. Multilayer systems, new approaches based on active or intelligent packaging or materials with lower environmental impacts are in development [2].

Beverage cans are one of the most used multilayer packaging materials, made of aluminum with an inner epoxy resin coating to prevent direct contact between food or 
beverage and the aluminum surface [4]. Final coatings are obtained by the addition of components such as cross-linkers, solvents, pigments, anti-foaming agents, adhesion promoters, resins, and surfactants [5]. During the polymerization process, side reactions can occur, and linear or cyclic byproducts may be formed. These unknown chemicals may migrate into food resulting in consumer exposure [6].

Epoxy resins are commercially used in coatings because of their exceptional adhesion due to the presence of polar hydroxyl and ether groups in their structure [7]. Besides this technical advantage, some drawbacks regarding their safety can be found in the literature; some authors have shown the potential migration of bisphenol A (BPA) from these materials to food [8]. Epoxy monomers such as bisphenol A-diglycidyl ether (BADGE) have been extracted from epoxy resins [9] and found in food simulants after migration assays [10], and other BADGE-based derivatives from epoxy coatings were also identified by Schaefer et al. [11].

Commission Regulation (EU) No. 10/2011 [12] established specific rules for plastic materials intended to come in contact with food. Currently, there is no specific European legislation for coatings. Both intentionally added substances (IAS) and non-intentionally added substances (NIAS) such as impurities, reaction byproducts, and degradation products can migrate into food, and they should be evaluated.

These migrants may also be oligomers, prepolymers, catalyst, reaction accelerators, epoxidized edible oils, esters, waxes, lubricants, metals, etc. [13,14]. The migration of these chemicals from packaging to food and beverage is one of the main concerns of food safety authorities.

Non-targeted methods using LC-MS or GC-MS are being widely employed for the identification of potential migrants in food packaging. Both techniques provide essential and complementary information necessary for a complete characterization of packaging materials. In GC-MS analysis, the use of commercial libraries helps the identification, although in the case of NIAS, they usually are not present in the databases. Bradley et al. [15] carried out an analysis via headspace GC-MS and a solvent extraction with acetonitrile followed by GC-MS to determine volatile compounds in epoxy phenolic can coatings. The authors detected bisphenol A, used as a starting substance in the manufacturing of the coating. More recently, Omer et al. [16] used GC-MS with different ionization sources, namely electron ionization (EI) and atmospheric pressure chemical ionization (APCI), and different mass spectrometers, specifically quadrupole, time-of-flight, and orbitrap, to investigate potential migrants in polyester-polyurethane lacquers. Several cyclic oligoester tetramers were identified in the two lacquers tested. In another study reported in the literature, GC-MS and highly accurate mass spectrometry was used for the analysis of bisphenol A alternative food-contact metal can coatings. Cyclic polyester oligomers from polyester-based coatings and bisphenol-type compounds, including tetramethyl bisphenol F, tetramethyl bisphenol F diglycidyl ether, and bisphenol F, among others, were identified [3].

The aim of this work was to develop a screening method for the identification of volatile compounds in polymeric coatings of metal cans for beverage packaging. For that purpose, a method based on solid-liquid extraction followed by gas chromatography-mass spectrometry (GC-MS) and a method based on solid-phase microextraction in headspace mode and gas chromatography coupled with mass spectrometry (HSSPME-GC-MS) were optimized.

\section{Materials and Methods}

\subsection{Sample Description and FTIR Characterization}

A total of ten beverages packed in metal cans were bought in local supermarkets in Santiago de Compostela (Spain). All of them were two-piece cans. The internal surface of metal cans is often coated with a polymeric coating (with a thickness of about $2 \mu \mathrm{m})$ to preserve food and avoid metal corrosion. The thickness of the samples analyzed (metal + coating) is provided in Table 1. The thickness of the packaging was measured with a manual digital micrometer (Mitutoyo-Japan, Kanagawa, Japan). The polymeric coatings were analyzed by using an attenuated total reflectance FTIR spectrometer and 
were identified using the KnowItAll ${ }^{\circledR}$ 17.4.135.B IR Spectral Libraries of Polymers and Related Compounds (Bio-Rad Laboratories, Inc., Hercules, CA, USA).

Table 1. Sample descriptions.

\begin{tabular}{|c|c|c|c|}
\hline Code & Beverage & Polymeric Coating & Thickness $(\mu \mathrm{m})$ \\
\hline BC01 & Traditional Beer & $\begin{array}{l}\text { Lat. Ext.: PU } \\
\text { Lat. Int.: Phx } \\
\text { Lid Int.: Phx } \\
\text { Lid Ext.: Phx }\end{array}$ & $\begin{array}{l}\text { Lateral: } 114.5 \\
\text { Lid: } 313.0\end{array}$ \\
\hline BC02 & Vodka mixed drink & $\begin{array}{l}\text { Lat. Ext.: PU } \\
\text { Lat. Int.: Phx } \\
\text { Lid Int.: Epx } \\
\text { Lid Ext.: Epx }\end{array}$ & $\begin{array}{l}\text { Lateral: } 109.0 \\
\text { Lid: } 218.0\end{array}$ \\
\hline BC03 & Mixed lemon flavour & $\begin{array}{l}\text { Lat. Ext.: PU } \\
\text { Lat. Int.: Phx } \\
\text { Lid Int.: Phx } \\
\text { Lid Ext.: Phx }\end{array}$ & $\begin{array}{l}\text { Lateral: } 104.0 \\
\text { Lid: } 218.0\end{array}$ \\
\hline BC04 & Energy Drink Zero & $\begin{array}{l}\text { Lat. Ext.: PU } \\
\text { Lat. Int.: Phx } \\
\text { Lid Int.: Epx } \\
\text { Lid Ext.: Epx }\end{array}$ & $\begin{array}{l}\text { Lateral: } 112.0 \\
\text { Lid: } 264.0\end{array}$ \\
\hline BC05 & $\begin{array}{c}\text { Star Wars Space } \\
\text { Punch }\end{array}$ & $\begin{array}{l}\text { Lat. Ext.: PP } \\
\text { Lat. Int.: Acrylic } \\
\text { Lid Int.: Polyester } \\
\text { Lid Ext.: Phx }\end{array}$ & $\begin{array}{l}\text { Lateral: } 114.0 \\
\text { Lid: } 331.0\end{array}$ \\
\hline BC06 & Green cola & $\begin{array}{l}\text { Lat. Ext.: PU } \\
\text { Lat. Int.: Phx } \\
\text { Lid Int.: Phx } \\
\text { Lid Ext.: Phx }\end{array}$ & $\begin{array}{l}\text { Lateral: } 115.0 \\
\text { Lid: } 234.0\end{array}$ \\
\hline $\mathrm{BC} 07$ & Tonic original & $\begin{array}{l}\text { Lat. Ext.: PU } \\
\text { Lat. Int.: Phx } \\
\text { Lid Int.: Epx } \\
\text { Lid Ext.: Epx }\end{array}$ & $\begin{array}{l}\text { Lateral: } 111.0 \\
\text { Lid: } 258.0\end{array}$ \\
\hline BC08 & Tonic water original & $\begin{array}{l}\text { Lat. Ext.: PU } \\
\text { Lat. Int.: Phx } \\
\text { Lid Int.: Epx } \\
\text { Lid Ext.: Epx }\end{array}$ & $\begin{array}{l}\text { Lateral: } 113.0 \\
\text { Lid: } 230.0\end{array}$ \\
\hline ВC09 & Premium tonic water & $\begin{array}{l}\text { Lat. Ext.: PU } \\
\text { Lat. Int.: Acrylic } \\
\text { Lid Int.: Polyester } \\
\text { Lid Ext.: Phx }\end{array}$ & $\begin{array}{l}\text { Lateral: } 123.0 \\
\text { Lid: } 226.0\end{array}$ \\
\hline BC10 & $\begin{array}{l}\text { Natural mineral } \\
\text { water drink }\end{array}$ & $\begin{array}{l}\text { Lat. Ext.: PU } \\
\text { Lat. Int.: Phx } \\
\text { Lid Int.: Epx } \\
\text { Lid Ext.: Epx }\end{array}$ & $\begin{array}{l}\text { Lateral: } 103.0 \\
\text { Lid: } 248.0\end{array}$ \\
\hline
\end{tabular}

The $\mathrm{pH}$ of the beverage samples ranged between 2.56 and 6.60. A brief overview of the samples is presented in Table 1; and a more detailed description of the samples used in this study was described by Lestido-Cardama et al. [17]. 


\subsection{Sample Treatment}

\subsubsection{Solvent Extraction Procedure}

Samples were opened, emptied, and washed with warm water before analysis. Cans were cut into small pieces (approximately $0.5 \mathrm{~cm}^{2}$ ), then $0.8 \mathrm{~g}$ were weighted in a vial and $5 \mathrm{~mL}$ of methanol was added and afterward the vial was hermetically sealed. The extraction was performed in an oven at $70^{\circ} \mathrm{C}$ for $24 \mathrm{~h}$. One aliquot was then removed with a $0.22 \mu \mathrm{m}$ polytetrafluoroethylene (PTFE)-membrane filter and analyzed via GC-MS.

\subsubsection{SPME Procedure}

An SPME holder for manual sampling and commercial fibers was purchased from Supelco (Bellefonte, PA, USA). Fibers with different coating materials were tested: a divinylbenzene-Carboxen-polydimethylsiloxane (DVB/PDMS/CAR) fiber with 50-30 $\mu \mathrm{m}$ thickness and a Carboxen-polydimethylsiloxane (CAR-PDMS) fiber with $100 \mu \mathrm{m}$ thickness. Prior to use they were conditioned by inserting them into the GC injector according to the supplier's instructions: for $1 \mathrm{~h}$ at $270^{\circ} \mathrm{C}$ and $0.5 \mathrm{~h}$ at $250{ }^{\circ} \mathrm{C}$, respectively.

For each experiment, $0.8 \mathrm{~g}$ of each sample, previously cut into small pieces (approximately $0.5 \mathrm{~cm}^{2}$ ) were weighted into a $20 \mathrm{~mL}$ headspace vial and sealed with a PTFE-faced silicone septum (Cromlab, Barcelona, Spain). The SPME fiber was put into the vial, and this was heated at $100^{\circ} \mathrm{C}$ for $30 \mathrm{~min}$. The fiber was then desorbed into the GC injector for $10 \mathrm{~min}$ at $200^{\circ} \mathrm{C}$. The compounds absorbed by the fiber were separated via gas chromatographic analysis and identified using the MS detector operating in the described conditions below.

\subsection{Reagents and Analytical Standards}

Acetonitrile HPLC grade, methanol, and hexane GC-MS grade were supplied by Merck (Darmstadt, Germany). Ethanol for analysis was supplied by Merck (Darmstadt, Germany). The 2-butoxyethanol, spectrophotometric grade with a purity of $\geq 99.0 \%, 2,2$ dimethyl-1,3-propanediol with a purity of $99.0 \%$, octanal with a purity of $99 \%$, D-Limonene, $\varepsilon$-Caprolactam; 2,6-Di-tert-butyl-1,4-benzoquinone with a purity of $98.0 \%$, diethyl phthalate with a purity of $99.5 \%$, benzophenone with a purity of $\geq 99.0 \%$, benzoic acid with a purity of $99.5 \%$, vanillin with a purity of $99.0 \%, 2,4$-ditertbutylphenol with a purity of $99.0 \%$, and $\alpha$-terpineol were purchased from Sigma Aldrich (Steinheim, Germany). Nonanal with purity of $98.7 \%$ was purchased from Supelco (Bellefonte, PA, USA). The 2-phenoxyethanol with purity of $\geq 99.0 \%$ was supplied by Fluka (Seelze, Germany). Working solutions were prepared by diluting different amounts of the stock standard solution in methanol.

\subsection{GC-MS Conditions for Solvent Extraction Samples}

A Trace 1300 gas chromatograph equipped with a programmed split/splitless injector, a 1310 autosampler, and an ISQ LT Single Quadrupole mass spectrometer (Thermo Electron Corp., Madison, WI, USA) were used to perform the GC analyses. The separation was performed on a Rxi-5Sil MS $(30 \mathrm{~m} \times 0.25 \mathrm{~mm} \times 0.25 \mu \mathrm{m})$ column from Restek (Bellefonte, PA, USA). The operating conditions were the following: the injector temperature was $300{ }^{\circ} \mathrm{C}$ and the temperature of the transfer line of the detector was $300{ }^{\circ} \mathrm{C}$. The oven temperature was set as follows: initially the temperature was set at $40^{\circ} \mathrm{C}$ for $2 \mathrm{~min}$, then increased at a rate of $9{ }^{\circ} \mathrm{C} / \mathrm{min}$ until $300^{\circ} \mathrm{C}$ and held for $12 \mathrm{~min}$. Injection was performed in splitless mode, and the injection volume was $1 \mu \mathrm{L}$. The carrier gas was helium with a flow rate of $1 \mathrm{~mL} / \mathrm{min}$. The mass spectrometer was operated in electron impact ionization mode with a full scan range between 20 and $500 \mathrm{~m} / z$.

Data analysis was performed using Xcalibur version 4.1 and the NIST/EPA/NIH 11 mass spectral library (version 2.0) and Wiley Registry TM 8th edition database were used for identification.

\subsection{GC-MS Conditions for SPME Analysis}

A Thermo Finnigan Trace GC gas chromatograph and a Finnigan Trace DSQ mass selective detector (Thermo Scientific, Waltham, MA, USA) were used to perform all GC 
analyses. For SPME analyses, an Rxi-624Sil MS (30 m $\times 0.25 \mathrm{~mm} \times 1.40 \mu \mathrm{m})$ column from Restek (Bellefonte, PA, USA) was used, and the separation of compounds was performed under the following operating conditions: the injector temperature was set at $200{ }^{\circ} \mathrm{C}$ and the transfer line temperature was $250{ }^{\circ} \mathrm{C}$. The ramp temperature was set from 45 to $250{ }^{\circ} \mathrm{C}$. The mass spectrometer operated in full scan mode (between 20 and $500 \mathrm{~m} / \mathrm{z}$ ).

Data analysis was performed using Xcalibur version 2.0.7 and the NIST/EPA/NIH 11 mass spectral library (version 2.0) and Wiley Registry TM 8th edition database were used for detection and identification.

In order to estimate the toxicity of the identified compounds, an in silico method, namely Cramer rules were applied. For that, the software Toxtree was used [18]. According to Cramer rules, substances are classified based on their chemical structure into Class I (low toxicity), Class II (intermediate toxicity) and Class III (high toxicity). Thus, Class I comprises substances with simple chemical structures such as common carbohydrates, acyclic aliphatic hydrocarbons, and so on. Class II includes substances that possess structures that are less innocuous than those of Class I but do not contain substances with structural features that suggest toxicity like substances of Class III. Examples of Class II substances are common components of food, substances containing no functional groups other than alcohol, aldehyde, acid, ester, etc. Class III includes substances with chemical structures that may suggest significant toxicity or contain reactive functional groups. Examples of substances belonging to this Class are certain benzene derivatives, certain heterocyclic substances, etc. [19].

\section{Results and Discussion}

\subsection{Solvent Selection for Can Extraction}

Different solvents were tested with the aim to extract compounds with different polarities present in the coating of metal cans. Samples were extracted under different conditions, both methanol and acetonitrile for $24 \mathrm{~h}$ at $70{ }^{\circ} \mathrm{C}$, hexane for $4 \mathrm{~h}$ at $60^{\circ} \mathrm{C}$, and a mixture of hexane and ethanol $(3: 1 \mathrm{v} / \mathrm{v})$ for $24 \mathrm{~h}$ at $20^{\circ} \mathrm{C}$. In Figure 1 , chromatograms obtained after extraction with different solvents are shown. Methanol was the solvent selected for extraction because more peaks were detected and identified. Table 2 lists the compounds detected after extraction with different solvents. As the analyzed samples were already in contact with the drink, some of the identified compounds may have their origin in food. On the other hand, it is interesting to note that flavorings are commonly used in these beverages, thus some of the detected compounds in the samples are authorized as food flavorings in the European Union [20]. These compounds are indicated in the table with their corresponding Flavis Number (FL No.). Some of them are, for example, benzoic acid methyl ester and caprylic acid methyl ester.

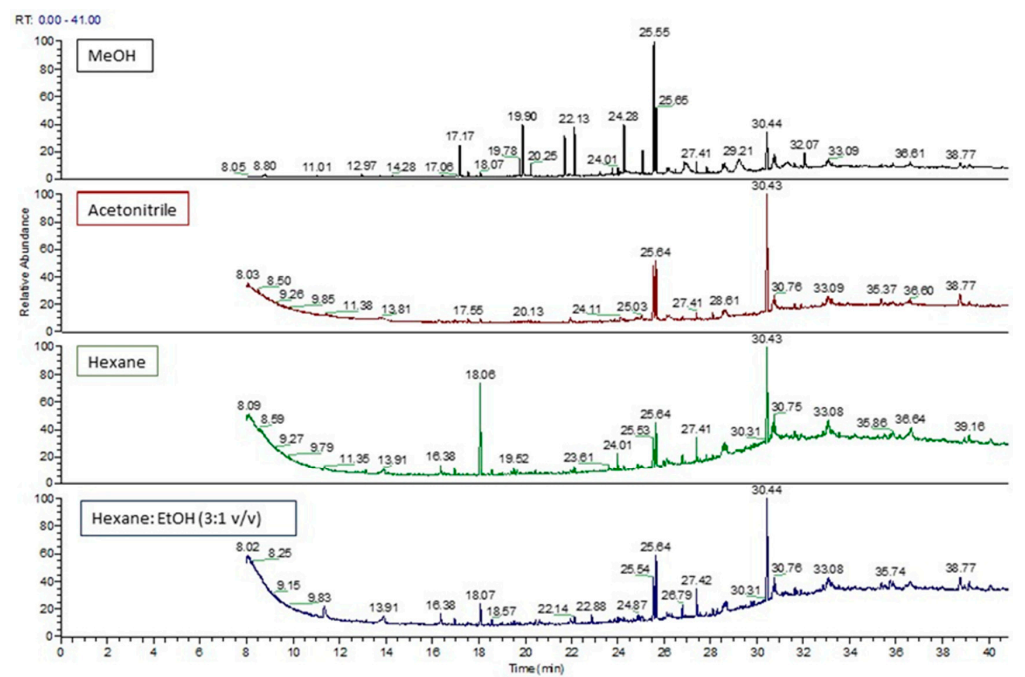

Figure 1. Chromatograms of sample BC04 extracted with different solvents. 
Table 2. Comparison of the most abundant detected compounds in sample BC04 using different extraction solvents.

\begin{tabular}{|c|c|c|c|c|c|c|c|}
\hline $\operatorname{Tr} / \mathrm{min}$ & Compound & CAS & Fl No. & $\mathrm{MeOH}$ & $\mathrm{ACN}$ & Hex & Hex: EtOH $(3: 1 v / v)$ \\
\hline 10.56 & Benzoic acid methyl ester & $93-58-3$ & 09.725 & $\mathrm{x}$ & & & \\
\hline 11.01 & Caprylic acid methyl ester & $111-11-5$ & 09.117 & $x$ & & & \\
\hline 12.97 & Adipic acid methyl ester & $627-93-0$ & & $x$ & & & \\
\hline 17.17 & Lauric acid methyl ester & $111-82-0$ & 09.101 & $\mathrm{x}$ & & & \\
\hline 17.55 & Unknown compound $(m / z$ 129) & & & $\mathrm{x}$ & & & \\
\hline 18.07 & Diethyl phthalate * & $84-66-2$ & & $x$ & & $x$ & $x$ \\
\hline 19.92 & Ester & & & $x$ & & & \\
\hline 20.25 & Unknown compound $(m / z 56)$ & & & $\mathrm{x}$ & & & \\
\hline 21.71 & Thiophene & & & $\mathrm{x}$ & & & \\
\hline 25.07 & Unknown compound $(m / z$ 151) & & & $x$ & & & \\
\hline 25.56 & Adipate structure & & & $x$ & $\mathrm{x}$ & $x$ & $\mathrm{x}$ \\
\hline 25.65 & Adipate structure & & & $\mathrm{x}$ & $x$ & $\mathrm{x}$ & $\mathrm{x}$ \\
\hline 30.43 & Unknown compound & & & $x$ & $x$ & $x$ & $x$ \\
\hline
\end{tabular}

Ester compounds were mainly identified in extraction with methanol as a solvent. Some studies show the migration of these types of compounds in cured varnishes used in food packaging [21]. In this work, samples were extracted with ethanol 95\% $(v / v)$. Adipic acid has been reported as a chemical intermediate used in the manufacturing of polyurethane resins [22].

\subsection{Optimization of SPME Method}

In the present work, a method based on solid-phase microextraction in headspace mode and gas chromatography coupled with mass spectrometry (HSSPME-GC-MS) was developed for the identification of potential migrants in polymeric coatings.

SPME is an easy, cheap, and clean method to use, although there is a for need further optimization in terms of equilibrium of experimental conditions such as heating temperature, extraction time, sample volume, concentration of volatiles, and sample matrix [23]. For that purpose, some parameters such as extraction time, equilibrium temperature, or the type of fiber were optimized.

The effect of extraction temperature, extraction time, and desorption time was evaluated using the fiber DVB-CAR-PDMS.

Firstly, the extraction time was optimized. Different times were tested (10, 30, and $60 \mathrm{~min})$, keeping extraction temperature $\left(40,70\right.$, and $\left.100{ }^{\circ} \mathrm{C}\right)$, equilibration time ( $\left.2 \mathrm{~min}\right)$, and desorption time $(10 \mathrm{~min})$ fixed. Under these conditions the best results were found at 30 and 60 min of extraction because more peaks were identified and with a higher intensity, and there was hardly any difference between the two tested times, therefore, $30 \mathrm{~min}$ of extraction was selected. Once the time of extraction was optimized, the temperature was studied ranging from 40 to $100{ }^{\circ} \mathrm{C}$. The difference in the sensitivity and the number of peaks detected was related with the increase of the temperature.

The effects of temperature and extraction time were evident from the chromatograms obtained under the following conditions: 40,70 , and $100{ }^{\circ} \mathrm{C}$ for 10, 30, and $60 \mathrm{~min}$. An increase in the peak chromatographic area was found, especially with the less volatile compounds at higher temperatures.

Machiels et al. [24] reported that highly volatile compounds were not affected by desorption time and less volatile compounds needed more time to desorb. 
The next parameter that was optimized was the amount of the sample used, which was considered between $0.8 \mathrm{~g}$ and $2 \mathrm{~g}$. Finally, the amount $0.8 \mathrm{~g}$ was chosen because larger amounts of sample did not lead to higher intensity of the chromatographic peaks.

It is important to get a well-balanced compromise between sensitivity and extraction rate, particularly with respect to the extraction temperature, to achieve a careful optimization of each parameter.

Best results and with the higher peak intensities were obtained for $30 \mathrm{~min}$ at $100{ }^{\circ} \mathrm{C}$ with 2 min of equilibration time and 10 min of desorption time.

\section{Selection of the Type of Fiber}

The selection of the fiber and SPME extraction conditions can affect the sensitivity and accuracy of SPME analysis. Park et al. [25] affirmed that using two-phase fibers (Carboxen-PDMS) seems to be more suitable for measuring low molecular weight compounds, whereas three-phase fibers (DVB-Carboxen on PDMS) appeared to be more appropriate for measuring high molecular weight compounds. DVB-CAR-PDMS fiber has shown the best sorption capacity for some compounds such as food packaging contaminants in alcoholic beverages.

In our study, a DVB/PDMS/CAR fiber with 50-30 $\mu \mathrm{m}$ thickness and a CAR-PDMS with $100 \mu \mathrm{m}$ thickness were tested. Peak areas from decanal, 2-oxepanone and diethylphthalate, which were the most abundant peaks, were compared between both types of fibers, with the first one achieving the higher response. This fact confirms that DVB/PDMS/CAR fiber is more appropriate to separate volatile compounds with higher molecular weight.

\subsection{Can Coatings Analysis via GC after a Solvent Extraction}

GC-MS was used to tentatively identify semi-volatile compounds that could potentially migrate from polymeric coatings. A GC-MS method that covered a wide mass range (from 35 to $500 \mathrm{~m} / z$ ) with a suitable gradient of temperatures was used. Samples were injected in splitless mode. Results obtained are shown in Table 3. Only compounds with appropriate direct matching factors (SI) and reverse search matching (RSI) are identified in Table 3. In general, values of 900 or greater are considered an excellent match, 800-900 a good match, and 700-800 a fair match. For those compounds whose identification was not achievable, the most abundant $m / z$ is specified.

Table 3. Compounds identified via GC-MS analysis after extraction with $\mathrm{MeOH}$ as a solvent.

\begin{tabular}{|c|c|c|c|c|c|c|c|}
\hline $\operatorname{Tr} / \mathrm{min}$ & Compound & CAS & Fl No. & SI & RSI & Sample(s) & TC \\
\hline 10.56 & Benzoic acid methyl ester & $93-58-3$ & 09.725 & 745 & 857 & BC04 & I \\
\hline 11.01 & Caprylic acid methyl ester & $111-11-5$ & 09.117 & 701 & 789 & BC04 & I \\
\hline 11.37 & 2-Oxepanone & $502-44-3$ & & 729 & 862 & $\mathrm{BC} 06, \mathrm{BC} 07$ & I \\
\hline 12.34 & $\alpha$-Terpineol * & $98-55-5$ & 02.014 & 902 & 936 & 9 & III \\
\hline 12.97 & Adipic acid methyl ester & $627-93-0$ & & 794 & 867 & $\begin{array}{c}\mathrm{BC} 01, \mathrm{BC} 03, \mathrm{BC} 04, \\
\text { BC06-BC08 }\end{array}$ & I \\
\hline 14.2 & Isobenzofuran-1,3-dione & $85-44-9$ & & 841 & 922 & $\begin{array}{l}\mathrm{BC} 02, \mathrm{BC} 05, \mathrm{BC} 07, \\
\text { BC10 }\end{array}$ & III \\
\hline 15.58 & Unknown diol & & & & & $\mathrm{BC} 05$ & \\
\hline 16.93 & (+)-Ledene & $21747-46-6$ & & 893 & 927 & BC09 & I \\
\hline 17.17 & Lauric acid methyl ester & $111-82-0$ & 09.101 & 855 & 878 & BC01-BC10 & I \\
\hline 17.55 & Ester structure $(m / z$ 129) & & & & & BC01-BC10 & \\
\hline 18.08 & Diethyl phthalate * & $84-66-2$ & & 929 & 938 & $\begin{array}{l}\mathrm{BC} 01-\mathrm{BC} 05, \mathrm{BC} 09 \\
\text { BC10 }\end{array}$ & I \\
\hline 18.37 & Unknown compound $(m / z 107,163)$ & & & & & BC09 & \\
\hline 19.28 & Dodecalactone & $2305-05-7$ & 10.019 & 855 & 894 & $\mathrm{BC} 05$ & II \\
\hline 19.92 & Ester structure $(m / z 129)$ & & & & & $\mathrm{BC} 01-\mathrm{BC} 10$ & \\
\hline 20.29 & Unknown compound $(m / z 56,111)$ & & & & & BC08 & \\
\hline
\end{tabular}


Table 3. Cont.

\begin{tabular}{|c|c|c|c|c|c|c|c|}
\hline $\mathrm{Tr} / \mathrm{min}$ & Compound & CAS & F1 No. & SI & RSI & Sample(s) & TC \\
\hline 20.72 & Butyl octyl phthalate & $84-78-6$ & & 714 & 758 & $\mathrm{BC} 02$ & I \\
\hline 20.99 & Ketone structure & & & & & $\mathrm{BC} 05, \mathrm{BC} 07$ & \\
\hline 21.53 & Unknown compound $m / z(45,109)$ & & & & & BC05 & \\
\hline 21.73 & 2-Isobutyl-5-propylthiophene & $4861-63-6$ & & & & $\begin{array}{l}\mathrm{BC} 01-\mathrm{BC} 06, \\
\mathrm{BC} 08-\mathrm{BC} 10\end{array}$ & III \\
\hline 21.99 & $\begin{array}{c}\text { 7,9-Di-tert-butyl-1- } \\
\text { oxaspiro[4,5]deca-6,9-diene-2,8- } \\
\text { dione }\end{array}$ & $82304-66-3$ & & & & BC05 & III \\
\hline 22.33 and 23.3 & $\begin{array}{l}\text { Unknown compound (Phthalate } \\
\text { structure } m / z: 149 \text { ) }\end{array}$ & & & & & $\mathrm{BC} 02, \mathrm{BC} 05, \mathrm{BC} 07$ & \\
\hline 23.81 & Unknown compound $(m / z$ 151) & & & & & BC06-BC08, BC10 & \\
\hline 25.08 & Unknown compound $(m / z$ 151) & & & & & $\begin{array}{l}\mathrm{BC} 01, \mathrm{BC} 02, \mathrm{BC} 04 \\
\text { BC08-BC10 }\end{array}$ & \\
\hline 25.56 & Unknown compound $(m / z 129,111)$ & & & & & BC01-BC10 & \\
\hline 25.65 & Unknown compound $(m / z 129,111)$ & & & & & ВC01-BC010 & \\
\hline 26.53 & Unknown compound $(m / z$ 163) & & & & & $\mathrm{BC} 08, \mathrm{BC} 10$ & \\
\hline 27.19 & $\begin{array}{l}\alpha \text {-Methyl- } \delta \text {-oxo-2-phenyl-1,3- } \\
\text { dioxolane-2-heptanenitrile }\end{array}$ & $58422-90-5$ & & 782 & 940 & $\begin{array}{l}\mathrm{BC} 02, \mathrm{BC} 05, \mathrm{BC} 07 \\
\text { BC09, } \mathrm{BC} 10\end{array}$ & III \\
\hline 27.42 & Hexa(methoxymethyl)melamine & $68002-20-0$ & & 857 & 874 & $\begin{array}{l}\text { BC01- BC03, BC05, } \\
\text { BC08, BC10 }\end{array}$ & III \\
\hline 27.87 & Unknown compound $(m / z 143,111)$ & & & & & BC08 & \\
\hline 28.4 & $\begin{array}{l}\text { Unknown compound (Phthalate } \\
\text { structure } m / z \text { 149) }\end{array}$ & & & & & $\begin{array}{l}\mathrm{BC} 02, \mathrm{BC} 05, \mathrm{BC} 07 \\
\mathrm{BC} 09, \mathrm{BC} 10\end{array}$ & \\
\hline 29.96 & Unknown compound $(m / z$ 301) & & & & & $\begin{array}{l}\mathrm{BC} 02, \mathrm{BC} 05, \\
\mathrm{BC} 09, \mathrm{BC} 10\end{array}$ & \\
\hline 30.46 & Unknown compound $(m / z 69,81)$ & & & & & BC08 & \\
\hline 32.45 & Unknown compound $(m / z 345)$ & & & & & $\begin{array}{l}\mathrm{BC} 02,5 \mathrm{BC} 0 \\
\mathrm{BC} 09, \mathrm{BC} 10\end{array}$ & \\
\hline 35.36 & $\begin{array}{l}\text { Unknown compound (Phthalate } \\
\text { structure } m / z: 149)\end{array}$ & & & & & ВC02, BC05, ВC010 & \\
\hline 35.95 & Unknown compound $(m / z$ 389) & & & & & ВC02, ВC05, ВC09 & \\
\hline
\end{tabular}

* Substances confirmed with a standard solution.

Volatile compounds coming from the beverage were detected. Thus, different esters (e.g., benzoic acid methyl ester, lauric acid methyl ester, etc.) were identified. Esters were reported by Dragone et al. [26] in alcoholic distilled beverages, which contribute to the greatest proportion of the total aroma. The analysis was performed using dichloromethane as an extraction solvent and the compounds were separated on a CP-Wax 52 CB ( $50 \mathrm{~m} \times 0.25 \mathrm{~mm}$ i.d., $0.2 \mu \mathrm{m}$ film thickness, Chrompack). Ledene, a sesquiterpene hydrocarbon, has also been found in natural products [27]. $\alpha$-Methyl- $\delta$-oxo-2-phenyl-1,3dioxolane-2-heptanenitrile has been reported as a precursor of thymol and a carvacrol and eugenol intermediary [28]. Moreover, flavorings authorized in the EU [20], such as $\alpha$-terpineol and dodecalactone, were identified in different samples. These substances belong to Class III and Class II, according to Cramer rules, respectively.

With respect to compounds coming from the packaging materials, several plasticizers, including phthalates (e.g., diethyl phthalate, butyl octyl phthalate), were identified in almost all samples. Chemicals of phthalate esters (PAEs) can act as endocrine disruptors and lead to adverse effects on organisms even in a low concentration [29]. They can also induce various etiological diseases of humans, such as disorders of the male reproductive tract, breast and testicular cancers, and dysfunction of the neuroendocrine system [30]. Isobenzofuran-1,3-dione, also called phthalic anhydride, was identified in samples $\mathrm{BC} 02, \mathrm{BC} 05, \mathrm{BC} 07$, and $\mathrm{BC} 10$. The most important derivatives of this compound 
are plasticizers and also polyester resins and dyes [31]. This compound has been classified as high toxicity (Class III), according to Cramer rules. Besides, it can be part of a curing agent system used during the manufacturing of an epoxy resin [32]. Other compounds identified include 2-oxepanone and hexa(methoxymethyl)melamine. The lactone has been reported as a degradation product of polyurethanes and in this study the analysis was carried out by pyrolysis-gas-chromatography/mass spectrometry [33], and hexa(methoxymethyl)melamine is widely employed as a cross-linking agent in coatings [34]. This compound belongs to Class III, according to Cramer rules. A NIAS compound, specifically 7,9-di-tert-butyl-1-oxaspiro[4,5]deca-6,9-diene-2,8-dione (Figure 2), was identified in sample $\mathrm{BC} 05$ and it presents high toxicity (Class III). This compound has been reported as a degradation product of the antioxidant Irganox 1010 and has been found in several samples of both plastic and paper packaging and in polyurethane adhesives $[35,36]$. In plastic materials the analyte was determined in aqueous extracts using the purge and trap method combined with GC-MS [36].

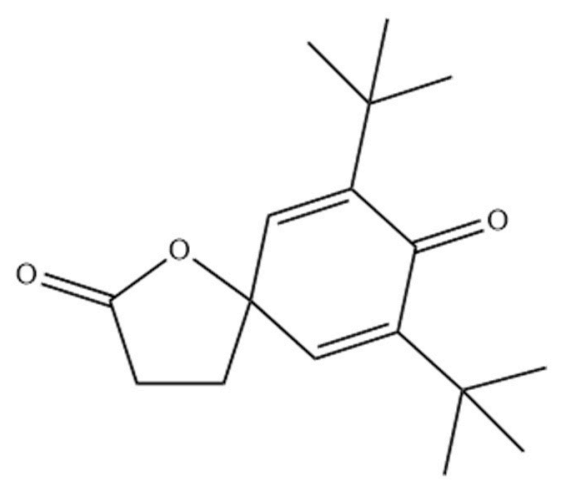

Figure 2. Chemical structure of 7,9-di-tert-butyl-1-oxaspiro[4,5]deca-6,9-diene-2,8-dione.

For some compounds, despite their high abundance, identification was not possible with the spectral libraries available, such as the compounds at $28.4 \mathrm{~min}(\mathrm{~m} / z 149$, which is the characteristic mass of phthalates compounds), $29.97 \mathrm{~min}(\mathrm{~m} / z$ 301), $32.45 \mathrm{~min}(\mathrm{~m} / \mathrm{z} 345)$, $35.37 \mathrm{~min}(\mathrm{~m} / z 149)$, and $35.95 \mathrm{~min}(\mathrm{~m} / z$ 389). Detailed information about the mass spectra of the unidentified compounds is available in the electronic Supplementary Material.

\subsection{Can Coatings Analysis via SPME}

The compounds detected after the extraction with SPME are summarized in Table 4. Only compounds with appropriate direct matching factors (SI) and reverse search matching (RSI) are included. For those compounds whose identification was not achievable, the most abundant $m / z$ is specified.

Table 4. Compounds identified via SPME GC-MS analysis.

\begin{tabular}{|c|c|c|c|c|c|c|c|}
\hline $\operatorname{Tr} / \mathrm{min}$ & Compound & CAS & F1 No. & SI & RSI & Sample(s) & TC \\
\hline 9.61 & Propylene glycol & $57-55-6$ & & 571 & 818 & $\mathrm{BC} 04$ & $\mathrm{I}$ \\
\hline 13.72 & 2-Butoxyethanol * & $111-76-2$ & 02.242 & 866 & 925 & BC01-BC10 & $\mathrm{I}$ \\
\hline 15.37 & $\alpha$-Terpinene & $99-86-5$ & 01.019 & 586 & 754 & BC09 & $\mathrm{I}$ \\
\hline 15.61 & Benzaldehyde & $100-52-7$ & 05.013 & 631 & 865 & BC01, BC05 & I \\
\hline 15.85 & 2,2-Dimethyl-1,3-Propanediol * & $126-30-7$ & & 821 & 892 & $\begin{array}{c}\mathrm{BC} 01, \mathrm{BC} 02, \mathrm{BC} 03, \\
\text { BC04, BC08 }\end{array}$ & I \\
\hline 16.11 & Octanal * & $124-13-0$ & 05.009 & 505 & 701 & $\mathrm{BC} 04$ & I \\
\hline 16.28 & 1,2,3,4-Tetramethyl benzene & $488-23-3$ & & 849 & 879 & BC09 & $\mathrm{I}$ \\
\hline 16.43 & Limonene * & $5989-27-5$ & 01.045 & 916 & 924 & $\begin{array}{l}\mathrm{BC} 02, \mathrm{BC} 03 \\
\mathrm{BC} 05-\mathrm{BC} 08\end{array}$ & I \\
\hline
\end{tabular}


Table 4. Cont

\begin{tabular}{|c|c|c|c|c|c|c|c|}
\hline $\mathrm{Tr} / \mathrm{min}$ & Compound & CAS & Fl No. & SI & RSI & Sample(s) & TC \\
\hline 16.5 & p-Cymene & $99-87-6$ & 01.002 & 909 & 926 & $\begin{array}{l}\mathrm{BC} 02, \mathrm{BC} 03 \\
\mathrm{BC} 06, \mathrm{BC} 09\end{array}$ & I \\
\hline 16.69 & 1-Hexanol-2-ethyl & $104-76-7$ & 02.082 & 809 & 913 & ВC05, ВC06, ВC08 & I \\
\hline 17.05 & g-Terpinene & $99-85-4$ & 01.020 & 882 & 894 & ВC02, ВC09 & I \\
\hline 17.68 & Terpinolene & $586-62-9$ & 01.005 & 795 & 864 & $\mathrm{BC} 02$ & I \\
\hline 18.07 & Benzene structure & & & & & $\begin{array}{l}\mathrm{BC} 02, \mathrm{BC} 05 \\
\mathrm{BC} 07, \mathrm{BC} 09\end{array}$ & \\
\hline 18.45 & Nonanal * & $124-19-6$ & 05.025 & 701 & 857 & ВС01-BC04, ВС06 & I \\
\hline 19.02 & $\begin{array}{c}\text { Unknown compound }(m / z 79,121 ; \\
\text { cyclohexenol structure) }\end{array}$ & & & & & ВC05 & \\
\hline 19.35 and 20.51 & $\begin{array}{l}\text { Unknown compound ( } m / z \text { 134; } \\
\text { cyclohexanol structure) }\end{array}$ & & & & & ВC05 & \\
\hline 19.39 & Benzenemethanol & $60-12-8$ & 02.019 & 842 & 896 & $\mathrm{BC} 01, \mathrm{BC} 03$ & I \\
\hline 19.92 & Ethyl octanoate & $106-32-1$ & 09.111 & 913 & 938 & $\mathrm{BC} 01-\mathrm{BC} 03$ & I \\
\hline 20.35 & Octanoic acid & $124-07-2$ & 08.010 & 763 & 928 & $\mathrm{BC} 01, \mathrm{BC} 02$ & $\mathrm{I}$ \\
\hline 20.61 & Decanal & $112-31-2$ & 05.010 & 853 & 924 & $\begin{array}{l}\mathrm{BC} 02, \mathrm{BC} 04, \\
\mathrm{BC} 06-\mathrm{BC} 08\end{array}$ & I \\
\hline 20.74 & $\begin{array}{l}\text { Unknown compound }(m / z \text { 70, 119; ester } \\
\text { structure) }\end{array}$ & & & & & ВC05 & \\
\hline 20.92 & Benzoic acid * & $65-85-0$ & 08.021 & 917 & 931 & $\mathrm{BC} 04$ & I \\
\hline 21.43 & $\begin{array}{l}\text { Unknown compound }(m / z 109,71 ; \\
\text { cyclohexanol structure) }\end{array}$ & & & & & ВC05 & \\
\hline 21.5 & Unknown compound $(m / z 135,79,107)$ & & & & & $\mathrm{BC} 05, \mathrm{BC} 07$ & \\
\hline 21.67 & 2-Phenoxyethanol * & $122-99-6$ & & 696 & 965 & BC04 & I \\
\hline 21.68 & 2-Phenethyl acetate & $103-45-7$ & 09.031 & 822 & 911 & BC01 & I \\
\hline 21.76 & Carvone & $99-49-0$ & 07.012 & 860 & 914 & ВC05, ВC07, ВС09 & II \\
\hline 22.15 & Nonanoic acid & $112-05-0$ & 08.029 & 806 & 915 & BC01, BC04 & I \\
\hline 22.36 & Unknown compound $(m / z 73)$ & & & & & $\mathrm{BC} 03$ & \\
\hline 22.47 & Undecanal & $112-44-7$ & 05.034 & 633 & 824 & BC04 & I \\
\hline 22.98 & 2-Azepanone * & $105-60-2$ & 16.052 & 883 & 889 & BC01, BC03-BC10 & III \\
\hline 23.57 & Ethyl-decanoate & $110-38-3$ & 09.059 & 902 & 935 & ВC01-BC03, ВС05 & I \\
\hline 23.92 & Decanoic acid & $334-48-5$ & 08.011 & 671 & 775 & $\mathrm{BC} 04$ & I \\
\hline 24.25 & Dodecanal & $112-54-9$ & 05.011 & 606 & 872 & $\mathrm{BC} 02, \mathrm{BC} 06, \mathrm{BC} 07$ & $\mathrm{I}$ \\
\hline 24.68 & 2-Methylaminobenzoic acid & $85-91-6$ & 09.781 & 676 & 933 & $\mathrm{BC} 04$ & I \\
\hline 25.05 & 6,10-Dimethyl-5,9-undecadien-2-one & $3796-70-1$ & 07.123 & 688 & 773 & $\mathrm{BC} 02$ & I \\
\hline 25.39 & Benzaldehyde-4-hydroxy-3-methoxy * & $121-33-5$ & 05.018 & 830 & 904 & $\mathrm{BC} 04$ & I \\
\hline 25.51 & Napthalene structure & & & 792 & 833 & BC09 & \\
\hline 25.54 & $\begin{array}{l}\text { 2, 6-Di-tert-butyl-1,4-benzoquinone } \\
(2,6-D T B Q) *\end{array}$ & $719-22-2$ & & 729 & 804 & ВC06 & II \\
\hline 25.77 & 1,3-Diacetylbenzene & $6781-42-6$ & & 818 & 875 & BC01 & I \\
\hline 26.34 & 2,4-Ditertbutylphenol & $97-76-4$ & & & & $\begin{array}{l}\mathrm{BC} 03, \mathrm{BC} 06-\mathrm{BC} 08 \\
\text { BC10 }\end{array}$ & I \\
\hline 26.40 & Decalactone-g & 706-14-9 & 10.017 & 887 & 912 & ВC05, ВC09 & II \\
\hline 26.49 & $\begin{array}{l}\text { Unknown compound ( } m / z \text { 43, 163,120; } \\
\text { phenol structure) }\end{array}$ & & & & & ВC01 & \\
\hline 26.78 & Dodecanoate-ethyl & $106-33-2$ & 09.099 & 879 & 935 & BC01 & I \\
\hline 27.39 & $\begin{array}{l}\text { Unknown compound }(m / z \text { 129, } 111 ; \\
\text { ester structure })\end{array}$ & & & & & $\mathrm{BC} 03$ & \\
\hline 27.75 & Diethyl phthalate * & $84-66-2$ & & 922 & 930 & BC01-BC10 & I \\
\hline 28.03 & Undecalactone-g & $104-67-6$ & 10.002 & 755 & 849 & $\mathrm{BC} 05, \mathrm{BC} 07$ & II \\
\hline
\end{tabular}


Table 4. Cont.

\begin{tabular}{|c|c|c|c|c|c|c|c|}
\hline $\mathrm{Tr} / \mathrm{min}$ & Compound & CAS & Fl No. & SI & RSI & Sample(s) & TC \\
\hline 28.28 & Unknown compound $(m / z 213,109)$ & & & & & BC05 & \\
\hline 28.32 & Alcohol & & & & & BC01, BC04 & \\
\hline 28.60 & Diphenylmethanone * & $119-61-9$ & 07.032 & 717 & 941 & ВС01- ВС03 & III \\
\hline 29.56 & Lactone structure & & & & & BC05 & \\
\hline 29.69 & $\begin{array}{l}\text { Unknown compound ( } m / z 81,99 ; \\
\text { methanone structure })\end{array}$ & & & & & BC01, BC07 & \\
\hline 30.07 & Tetradecanoate & $110-27-0$ & 09.105 & 619 & 848 & BC01, BC04 & $\mathrm{I}$ \\
\hline 30.65 & Unknown compound $(m / z 219,191)$ & & & & & BC08 & \\
\hline 30.85 & Unknown compound $(m / z$ 69) & & & & & BC08 & \\
\hline 31.85 & Phthalate structure $(m / z$ 149) & & & & & BC04, BC08 & \\
\hline
\end{tabular}

* Substances confirmed with a standard solution.

Most of the substances identified are food flavorings authorized in EU. For example, $\alpha$ terpinene, benzaldehyde, 1-hexanol-2-ethyl, limonene, nonanal, carvone, ethyl-decanoate, and 2-azepanone, among others. Limonene provides a pleasant lemon scent; it is a common compound found in natural products such as resins of plants and in consumer goods such as fruit juices and juices beverages. Additionally, it is used as a raw material to manufacture cardboard or paper $[37,38]$. In the case of nonanal, it has also been detected in several materials, e.g., paper, polyethylene and polypropylene. It is characterized by a strong odor. The analysis was performed either via gas chromatography-olfactometry-mass spectrometry (GC-O-MS) or by aroma extract dilution analysis with dichloromethane [37,39]. Other common compounds also detected via GC-O-MS were 1-hexanol-2-ethyl, which is produced on a massive scale as a solvent and also as a precursor for the production of plasticizers with a green odor [37]. Benzaldehyde, which was detected in samples BC01 and $\mathrm{BC} 05$, has been reported in recycled cardboard [40] as well in adhesives [41]. Moreover, it is a very common natural flavor that might be present in beverages. 2-Azepanone, also known as caprolactam, was detected in all samples analyzed except in sample BC02; besides its use as food flavoring it has a widespread use in food packaging materials and clothing. For example, it was used in coating powders for protective films to block isocyanates [42]. Carcinogenicity studies had considered that 2-azepanone was not carcinogenic under the conditions of the bioassay in F344 rats and B6C3F1 mice [43]. DEP was also extracted with SPME, and this phthalate is the most commonly used plasticizer worldwide in many industrial products, including tools, automotive parts, toothbrushes, food packaging, cosmetics, and insecticides [44]. 2-Butoxyethanol, which was present in all samples, is used as a solvent in coatings formulation [45]. Diphenylmethanone or benzophenone was detected in samples $\mathrm{BC} 01, \mathrm{BC} 02$, and $\mathrm{BC} 03$; this substance has been used in polymeric photoinitiators for UV curing coatings [46].

Other compounds like tetramethyl benzenes have been reported in apple juice. The analytes were isolated via SPME using a 50/30 $\mu \mathrm{m}$ divinylbenzene/Carboxen/polydimethylsiloxane (DVB/CAR/PDMS) fiber [47].

Other compounds identified in several samples were propylene glycol and 2,2-dimethyl1,3-propanediol, also known as neopentyl glycol, which are commonly employed in the manufacturing of polyurethanes [48,49].

2-Phenoxyethanol was only identified in sample BC04. This compound has been reported in TritanTM copolyester, a potential substitute of polycarbonate. The compound was determined in aqueous extracts purified with solid-phase extraction (SPE) and then analyzed via GC-MS [50]. Degradation products of the antioxidants Irgafos 168, Irganox 1076, or Irganox 1010, specifically 2,4-ditertbutylphenol and 2, 6-di-tert-butyl-1,4-benzoquinone, were identified in various samples [51]. 2, 6-Di-tert-butyl-1,4-benzoquinone presents intermediate toxicity (Class II). These compounds have been reported as NIAS. Only two of the identified compounds, 2-azepanone and diphenylmethanone, belong to Cramer Class III. 


\section{Conclusions}

A wide variety of volatile and semi-volatile low molecular weight compounds were identified in polymeric coatings for metal beverage cans via solvent extraction and SPME followed by GC-MS. Fifty-six compounds were detected when using HS-SPME-GC-MS and 35 when the extraction solvent was applied. Esters were the predominant compounds determined via solvent extraction, whereas aromatic compounds and aldehydes were the most abundant compounds determined via SPME. From our results, the SPME method seems to be a more suitable identification technique, in terms of the number of compounds detected, and in general good library matches were obtained compared to the other technique. Besides, it is an eco-friendly and solvent-free extraction technique.

Supplementary Materials: The following are available online at https:/ /www.mdpi.com/article/10 .3390/ma14133704/s1, Figure S1-S30: Mass spectra of unknown compounds.

Author Contributions: Conceptualization, R.S., P.P.-L. and A.R.-B.d.Q.; methodology, R.S., P.P.-L., J.L.-H. and A.R.-B.d.Q.; investigation, P.V.-L. and A.L.-C.; writing-original draft preparation, P.V.-L.; writing-review and editing, P.P.-L., R.S. and A.R.-B.d.Q.; supervision, P.P.-L., R.S., A.R.-B.d.Q. and J.L.-H.; project administration, A.R.-B.d.Q. and R.S.; funding acquisition, A.R.-B.d.Q. All authors have read and agreed to the published version of the manuscript.

Funding: This research was funded by the Ministerio de Ciencia, Innovación y Universidades, by the Fondo Europeo de Desarrollo Regional (FEDER), and by the Agencia Estatal de Investigación Ref. No. PGC2018-094518-B-I00 “MIGRACOATING” (MICIU/FEDER, UE).

Institutional Review Board Statement: Not applicable.

Informed Consent Statement: Not applicable.

Data Availability Statement: The data presented in this study are available in [Identification of Volatile and Semi-Volatile Compounds in Polymeric Coatings Used in Metal Cans by GC-MS and SPME and Supplementary Material Identification of volatile and semi-volatile compounds in polymeric coatings used in metal cans by GC-MS and SPME].

Acknowledgments: The authors are grateful to the Ministerio de Ciencia, Innovación y Universidades for the predoctoral fellowship (ref. PRE2019-088195) awarded to P.V.-L.; A.L.-C. is grateful for her grant Programa de axudas á etapa predoutoral da Xunta de Galicia (Consellería de Cultura, Educación e Ordenación Universitaria).

Conflicts of Interest: The authors declare no conflict of interest.

\section{References}

1. EFSA CEF Panel (EFSA Panel on Food Contact Materials, Enzymes, Flavourings and Processing Aids). Note for guidance for the preparation of an application for the safety assessment of a substance to be used in plastic food contact materials. EFSA J. 2008, 6 . [CrossRef]

2. Marsh, K.; Bugusu, B. Food packaging-Roles, materials, and environmental issues. J. Food Sci. 2007, 72, R39-R55. [CrossRef]

3. Zhang, N.; Scarsella, J.B.; Hartman, T.G. Identification and quantitation studies of migrants from BPA alternative food-contact metal can coatings. Polymers 2020, 12, 2846. [CrossRef]

4. Kremser, K.; Gerl, P.; Pellis, A.; Guebitz, G.M. A new bioleaching strategy for the selective recovery of aluminum from multi-layer beverage cans. Waste Manag. 2021, 120, 16-24. [CrossRef]

5. Edlund, U.; Albertsson, A.-C. Polyesters based on diacid monomers. Adv. Drug Deliv. Rev. 2003, 55, 585-609. [CrossRef]

6. Pietropaolo, E.; Albenga, R.; Gosetti, F.; Toson, V.; Koster, S.; Marin-Kuan, M.; Veyrand, J.; Patin, A.; Schilter, B.; Pistone, A.; et al. Synthesis, identification and quantification of oligomers from polyester coatings for metal packaging. J. Chromatogr. A 2018, 1578, 15-27. [CrossRef]

7. Oprea, S.; Vlad, S.; Stanciu, A.; Macoveanu, M. Epoxy urethane acrylate. Eur. Polym. J. 2000, 36, 373-378. [CrossRef]

8. Munguía-López, E.M.; Gerardo-Lugo, S.; Peralta, E.; Bolumen, S.; Soto-Valdez, H. Migration of bisphenol A (BPA) from can coatings into a fatty-food simulant and tuna fish. Food Addit. Contam. 2005, 22, 892-898. [CrossRef]

9. Paseiro Losada, P.; Paz Abuín, S.; Vázquez Odériz, L.; Simal Lozano, J.; Simal Gándara, J. Determination of residual free monomers (m-xylylenediamine and bisphenol A diglycidyl ether) in the finished product. J. Chromatogr. A 1991, 585, 75-81.

10. Losada, P.P.; Mahia, P.L.; Odériz, L.V.; Lozano, J.S.; Gándara, J.S. Sensitive and rapid reversed-phase liquid chromatographyfluorescence method for determining bisphenol A diglycidyl ether in aqueous-based food simulants. J. Assoc. Off. Anal. Chem. 1991, 74, 925-928. [CrossRef] 
11. Schaefer, A.; Simat, T.J. Migration from can coatings: Part 3. Synthesis, identification and quantification of migrating epoxy-based substances below 1000 Da. Food Addit. Contam. 2004, 21, 390-405. [CrossRef] [PubMed]

12. European Commission. Commission Regulation (EU) No 10/2011 on plastic materials and articles intended to come into contact with food. Off. J. Eur. Union 2011, 12, 1-89.

13. Geueke, B. FPF Dossier: Can Coatings; Food Packaging Forum: Zurich, Switzerland, 2016.

14. Paseiro-Cerrato, R.; Devries, J.; Begley, T.H. Evaluation of short-term and long-term migration testing from can coatings into food simulants: Epoxy and acrylic-phenolic coatings. J. Agric. Food Chem. 2017, 65, 2594-2602. [CrossRef]

15. Bradley, E.L.; Driffield, M.; Harmer, N.; Oldring, P.K.T.; Castle, L. Identification of potential migrants in epoxy phenolic can coatings. Int. J. Polym. Anal. Charact. 2008, 13, 200-223. [CrossRef]

16. Omer, E.; Bichon, E.; Hutinet, S.; Royer, A.-L.; Monteau, F.; Germon, H.; Hill, P.; Remaud, G.; Dervilly-Pinel, G.; Cariou, R.; et al. Toward the characterisation of non-intentionally added substances migrating from polyester-polyurethane lacquers by comprehensive gas chromatography-mass spectrometry technologies. J. Chromatogr. A 2019, 1601, 327-334. [CrossRef]

17. Lestido-Cardama, A.; Loureiro, P.V.; Sendón, R.; Losada, P.P.; de Quirós, A.R.B. Application of chromatographic analysis for detecting components from polymeric can coatings and further determination in beverage samples. J. Chromatogr. A 2021, 1638, 461886. [CrossRef]

18. Toxtree v2.6.13. Available online: http:/ / toxtree.sourceforge.net/download.html (accessed on 10 May 2021).

19. Guidance document. Guidance on the use of the threshold of toxicological concern approach in food safety assessment. EFSA J. 2019, 17, e05708.

20. Regulation (EC) of the European Parliament and of the Council of 16 December 2008 No 1334/2008 on flavourings and certain food ingredients with flavouring properties for use in and on foods and amending Council Regulation (EEC) No 1601/91, Regulations (EC) No 2232/96 and (EC) No 110/2008 and Di-rective 2000/13/EC. Off. J. Eur. Union 2008, 354, 34-207.

21. Canellas, E.; Vera, P.; Nerín, C. Ion mobility quadrupole time-of-flight mass spectrometry for the identification of non-intentionally added substances in UV varnishes applied on food contact materials. A safety by design study. Talanta 2019, 205, 120103. [CrossRef] [PubMed]

22. Beardslee, T.; Picataggio, S. Bio-based adipic acid from renewable oils. Lipid Technol. 2012, 24, 223-225. [CrossRef]

23. Mirhosseini, H.; Salmah, Y.; Hamid, N.; Tan, C.P. Solid-phase microextraction for headspace analysis of key volatile compounds in orange beverage emulsion. Food Chem. 2007, 105, 1659-1670. [CrossRef]

24. Machiels, D. Evaluation of two commercial solid-phase microextraction fibres for the analysis of target aroma compounds in cooked beef meat. Talanta 2003, 61, 529-537. [CrossRef]

25. Park, S.-Y.; Yoon, Y.-M.; Schilling, M.W.; Chin, K.-B. Evaluation of volatile compounds isolated from pork loin (Longissimus dorsi) as affected by fiber type of Solid-Phase Microextraction (SPME), preheating and storage time. Food Sci. Anim. Resour. 2009, 29, 579-589. [CrossRef]

26. Dragone, G.; Mussatto, S.I.; Oliveira, J.M.; Teixeira, J.A. Characterisation of volatile compounds in an alcoholic beverage produced by whey fermentation. Food Chem. 2009, 112, 929-935. [CrossRef]

27. Mastelic, J.; Jerkovic, I. Gas chromatography-Mass spectrometry analysis of free and glycoconjugated aroma compounds of seasonally collected Satureja montana L. Food Chem. 2003, 80, 135-140. [CrossRef]

28. Iturbide-Zuñiga, A.S.; Colinas-León, M.T.B.; Lozoya-Saldaña, H.; Medina-Moreno, S.A.; Ayala-Arreola, J. Evaluación In Vitro de extractos del genero Lilium para el control de Fusarium oxysporum. Rev. Mex. Fitopatol. Mex. J. Phytopathol. 2017, 35, 611-622. [CrossRef]

29. Chen, W.-L.; Sung, H.-H. The toxic effect of phthalate esters on immune responses of giant freshwater prawn (Macrobrachium rosenbergii) via oral treatment. Aquat. Toxicol. 2005, 74, 160-171. [CrossRef]

30. Parkerton, T.; Konkel, W.J. Application of quantitative structure-activity relationships for assessing the aquatic toxicity of phthalate esters. Ecotoxicol. Environ. Saf. 2000, 45, 61-78. [CrossRef]

31. Lorz, P.M.; Towae, F.K.; Enke, W.; Jäckh, R.; Bhargava, N.; Hillesheim, W. Phthalic acid and derivatives. In Ullmann's Encyclopedia of Industrial Chemistry, 7th ed.; Wiley-VCH Verlag GmbH \& Co. KGaA: Weinheim, Germany, 2007; Volume 27, pp. 131-180.

32. Willy, B.; Neumann, M. Processing-Friendly Dianhydride Hardener for Epoxy Resin Systems Based on 5,5'-carbonylbis (isobenzofuran-1,3-dione). U.S. Patent Application No. US20150175740A1 14/575,397, 25 June 2015.

33. Zhang, Y.; Xia, Z.; Huang, H.; Chen, H. Thermal degradation of polyurethane based on IPDI. J. Anal. Appl. Pyrolysis 2009, 84, 89-94. [CrossRef]

34. Rauert, C.; Kaserzon, S.; Veal, C.; Yeh, R.Y.; Mueller, J.F.; Thomas, K.V. The first environmental assessment of hexa(methoxymethyl) melamine and co-occurring cyclic amines in Australian waterways. Sci. Total Environ. 2020, 743, 140834. [CrossRef]

35. Félix, J.S.; Isella, F.; Bosetti, O.; Nerín, C. Analytical tools for identification of non-intentionally added substances (NIAS) coming from polyurethane adhesives in multilayer packaging materials and their migration into food simulants. Anal. Bioanal. Chem. 2012, 403, 2869-2882. [CrossRef]

36. Skjevrak, I.; Brede, C.; Steffensen, I.-L.; Mikalsen, A.; Alexander, J.; Fjeldal, P.; Herikstad, H. Non-targeted multi-component analytical surveillance of plastic food contact materials: Identification of substances not included in EU positive lists and their risk assessment. Food Addit. Contam. 2005, 22, 1012-1022. [CrossRef]

37. Vera, P.; Canellas, E.; Nerín, C. Compounds responsible for off-odors in several samples composed by polypropylene, polyethylene, paper and cardboard used as food packaging materials. Food Chem. 2020, 309, 125792. [CrossRef] 
38. Wiedmer, C.; Velasco-Schön, C.; Buettner, A. Characterization of off-odours and potentially harmful substances in a fancy dress accessory handbag for children. Sci. Rep. 2017, 7, 1807. [CrossRef] [PubMed]

39. Tyapkova, O.; Czerny, M.; Buettner, A. Characterisation of flavour compounds formed by $\gamma$-irradiation of polypropylene. Polym. Degrad. Stab. 2009, 94, 757-769. [CrossRef]

40. Czerny, M. Odors in Paper and Cardboard Packaging; Springer Science and Business Media LLC: Berlin/Heidelberg, Germany, 2017; pp. $41-42$.

41. Vera, P.; Canellas, E.; Nerín, C. Migration of odorous compounds from adhesives used in market samples of food packaging materials by chromatography olfactometry and mass spectrometry (GC-O-MS). Food Chem. 2014, 145, 237-244. [CrossRef]

42. Pai Panandiker, K.A.; Danick, C. Coating Powders for Protective Films Based on Epsilon-Caprolactam Blocked Isocyanates. U.S. Patent Application No. 4395529A, 26 July 1983.

43. Program, N.T. Carcinogenesis Bioassay of Caprolactam (CAS No. 105-60-2) in F344 Rats and B6C3F1 Mice (Feed Study). Natl. Toxicol. Program Tech. Rep. Ser 1982, 214, 1-129.

44. Schettler, T. Human exposure to phthalates via consumer products. Int. J. Androl. 2006, 29, 134-139. [CrossRef]

45. Magami, S.M. Functional can coatings Part 2: Composition, attributes, applications and performance. Surf. Coat. Int. 2013, 96, 148-155.

46. Cheng, L.; Shi, W. Synthesis and photoinitiating behavior of benzophenone-based polymeric photoinitiators used for UV curing coatings. Prog. Org. Coat. 2011, 71, 355-361. [CrossRef]

47. Zepka, L.Q.; Garruti, D.S.; Sampaio, K.L.; Mercadante, A.Z.; Da Silva, M.A.A. Aroma compounds derived from the thermal degradation of carotenoids in a cashew apple juice model. Food Res. Int. 2014, 56, 108-114. [CrossRef]

48. Sawpan, M.A. Polyurethanes from vegetable oils and applications: A review. J. Polym. Res. 2018, 25, 184. [CrossRef]

49. Chiou, B.-S.; Schoen, P.E. Effects of crosslinking on thermal and mechanical properties of polyurethanes. J. Appl. Polym. Sci. 2001, 83, 212-223. [CrossRef]

50. Guart, A.; Wagner, M.; Mezquida, A.; Lacorte, S.; Oehlmann, J.; Borrell, A. Migration of plasticisers from Tritan ${ }^{\mathrm{TM}}$ and polycarbonate bottles and toxicological evaluation. Food Chem. 2013, 141, 373-380. [CrossRef] [PubMed]

51. Cardama, A.L.; Sendón, R.; Bustos, J.; Santillana, M.I.; Losada, P.P.; De Quirós, A.R.B. GC-MS screening for the identification of potential migrants present in polymeric coatings of food cans. Polymers 2019, 11, 2086. [CrossRef] 